\title{
KUALITAS ARTISTIK SENI ILUSTRASI KARYA LALA BOHANG PADA BUKU PUISI “THE BOOK OF FORBIDDEN FEELINGS"
}

\author{
Namirah Dwiyanthi Andi Amir \\ Prodi pendidikan Seni Rupa Fakultas Seni dan Desain Universitas Negeri Makassar \\ dwiyanti.namira@gmail.com
}

\begin{abstract}
ABSTRAK
Penelitian ini bertujuan untuk untuk mendeskripsikan kualitas artistik karya ilustrasi pada buku puisi "The Book of Forbidden Feelings" karya Lala Bohang berdasarkan (1) keartistikan wujud seni dan (2) keefektifan komunikasi gambar ilustrasi. Jenis penelitian ini adalah jenis penelitian analisis isi (content analysis) menggunakan pendekatan kritik seni yang dikemukakan oleh Edmund Burke Feldman. Teknik ini terdiri dari tiga tahapan, yaitu deskripsi, analisis formal, dan interpretasi. Sumber data dalam penelitian ini adalah naskah buku kumpulan puisi "The Book of Forbidden Feelings" terbitan PT. Gramedia Pustaka Utama (2017) karya Lala Bohang beserta sumber - sumber kajian pustaka yang membahas teori tentang seni rupa, ilustrasi, dan kritik seni terhadap karya Lala Bohang, didukung dengan data tambahan berupa tulisan artikel yang membahas buku ini, dan juga dokumen resmi lainnya. Pada penelitian ini terdapat 31 gambar ilustrasi karya Lala Bohang yang mendampingi teks puisi dalam buku kumpulan puisi "The Book of Forbidden Feelings" dan telah terpilih 10 gambar ilustrasi sebagai sampel yang dianggap dapat mewakili berdasarkan kualitas artistiknya. Sepuluh gambar ilustrasi yang terpilih memiliki beberapa perbedaan karakteristik yang terdiri dari bentuk, komposisi, latar dan ruang pada halaman buku yang terpakai. Karya tersebut dibuat menggunakan cat air yang dituangkan di atas kertas dengan penggunaan warna monochrome. Setiap gambar ilustrasi memiliki tema dan suasana yang berbeda sesuai dengan teks puisi yang didampinginya. Hasil penelitian ini yaitu; (1) Keartistikan wujud seni ilustrasi karya Lala Bohang pada buku kumpulan puisi "The Book of Forbidden Feelings". Karya ilustrasi ditampilkan dengan corak dekoratif dan menggunakan pemilihan warna seragam yang menggambarkan objek seperti manusia, hewan, tumbuhan, benda, dan ruang dengan keartistikan wujud yang baik keseluruhannya dengan komposisi yang harmonis dan bentuk - bentuk yang sederhana namun tetap kreatif dan dinamis. (2) Keefektifan komunikasi gambar ilustrasi karya Lala Bohang dalam mendampingi teks puisi pada buku "The Book of Forbidden Feelings". Tingkat keefektifan komunikasi gambar ilustrasi karya Lala Bohang cukup baik, tidak semua gambar ilustrasi menampilkan isi teks sebagaimana adanya, namun tetap memenuhi fungsinya dalam mendampingi karya sastra dengan cara memperkuat suasana sesuai dalam teks puisi dan menampilkan makna yang terkandung dalam masing - masing teks puisi.
\end{abstract}

Kata Kunci: Ilustrasi; Lala Bohang; Puisi

\begin{abstract}
This study aims to describe the artistic quality of the illustration works in Lala Bohang's "The Book of Forbidden Feelings" poetry book based on (1) the artistry form of the illustrations and (2) the effectiveness of illustrated image communication. This type of research used in this study is content analysis research using an art criticism approach introduced by Edmund Burke Feldman. This technique consists of three stages, namely description, formal analysis, and interpretation. The data source in this study is the physical copy of "The Book of Forbidden Feelings" poetry book published by PT. Gramedia Pustaka Utama (2017) by Lala Bohang along with literature sources that discuss theories about art, illustrations, and art criticism of Lala
\end{abstract}


Bohang's work, supported by additional data in the form of article writing that discusses this book, as well as other official documents. In this study there were 31 illustration works by Lala Bohang that each accompanies a poetry text in "The Book of Forbidden Feelings" poetry book and 10 illustrations were chosen as samples that are considered suitable in representing the others based on their artistic qualities. The ten selected illustrations have different characteristics which consist of the shape, composition, background and the space filled on the pages of the book. The works was made using watercolors applied on paper with the use of monochrome colors. Each illustrations has a different theme and atmosphere according to the poetic text they are accompanying. The results of this study are; (1) The artistry of Lala Bohang's illustrations in "The Book of Forbidden Feelings" poetry book. Illustrated works are displayed in decorative patterns and use uniformed color selection that depicts objects such as humans, animals, plants, furnitures, and lanscapes with a good form of artistry in it's entirety with harmonious compositions yet simple but still creative and dynamic forms. (2) Lala Bohang's illustrative images communication effectiveness in accompanying the poetry in "The Book of Forbidden Feelings" poetry book. The effectiveness of Lala Bohang's illustrated images communication is quite good, not all illustration images display the contents of the text as they are, but still fulfill their function in accompanying literary works by strengthening the appropriate atmosphere in poetic texts and displaying the meanings contained in each poetry. Each illustrations has a different theme and atmosphere according to the poetic text they are accompanying.

Keyword: Ilustratation; Lala Bohang; Rhymes

\section{PENDAHULUAN}

Istilah ilustrasi yang diambil dari bahasa Inggris Illustration, berasal dari bahasa Latin Illustrare yang berarti membuat terang. Ilustrasi adalah hasil visualisasi dari suatu tulisan menjadi sebuah gambar, lukisan, atau fotografi yang menekankan hubungan antara subjek dengan tulisan yang dimaksud, tetapi ilustrasi telah mengalami perkembangan yang menjadikannya sulit untuk dipahami jika berpijak pada pengertian tradisional yang hanya sebatas "gambar yang berfungsi untuk menjelaskan". Seni ilustrasi kontemporer tampil dalam bentuk yang semakin variatif, tidak hanya berupa "gambar", menjadi subjek ekspresif, bahkan berwujud abstrak dalam hal corak dan tema, sehingga tidak lagi sesuai dengan makna awal seni ilustrasi yang bertujuan untuk menerangkan atau menghiasi suatu cerita, tulisan, puisi, atau informasi tertulis lainnya yang dengan bantuan visual dapat lebih mudah dicerna.

Ilustrasi telah melewati perkembangan yang cukup panjang. Dalam masa perkembangannya seni ilustrasi tidak dapat melepaskan diri dari berbagai peristiwa yang terjadi dalam masyarakat yang secara langsung maupun tidak langsung mempengaruhi perkembangan seni ilustrasi dalam hal gagasan, fungsi, dan teknologi. Puisi sendiri secara garis besar yaitu sastra yang disusun dalam aksara berwujud berupa larik dan bait. Banyak yang berpendapat, puisi sulit dibedakan dengan novel bahkan cerpen apabila mereka juga disusun berbait-bait.

"The Book of Forbidden Feelings" merupakan sebuah buku kumpulan puisi karya Lala Bohang. Meskipun Lala Bohang tidak menyebutkan karyanya sebagai puisi, tetapi bukunya tersebut dapat dilihat sebagai puisi karena dalam buku tersebut disajikan gambar dan tulisan yang saling berkaitan membentuk ekspresi puitik. Tulisan dan gambar tersebut memang terlihat bercerita, tetapi dalam penyajiannya tidak terlihat adanya kelengkapan unsur-unsur prosa, seperti alur, latar, maupun tokoh. Karena itulah, karya tersebut dapat dikatakan sebagai sebuah puisi, berkata bahwa puisi adalah karya sastra dengan bahasa yang dipadatkan, dipersingkat, dan diberi rima dengan bunyi yang padu dan pemilihan kata-kata kias (Waluyo, 2002). Sastra berbentuk tulisan dan gambar yang disajikan membentuk ekspresi puitik sebagai sebuah inovasi dalam bersastra seiring dengan kemajuan teknologi informasi saat ini-selain karena Lala Bohang sendiri seorang desainer grafis. Hal itu sejalan dengan perkembangan sastra, (Damono, 2018) memaparkan bahwa 
teknologi tidak berniat memisahkan bunyi dan aksara (termasuk gambar), justru teknologi hadir menyandingkannya. Aksara itu sendiri merupakan sebuah gambar mati yang dicoretkan pada kertas atau media lainnya.

Ilustrasi yang mendampingi teks puisi dalam buku "The Book of Forbidden Feelings" ini membantu menyampaikan apa yang penyair ingin sampaikan dalam puisi ke dalam bentuk visual. Lala Bohang bereaksi terhadap setiap puisi sesuai tafsir dan perasaannya ketika menulis tiap sajaknya. Terkadang, ilustrasi yang ada tidak menampilkan objek sesuai pada puisi melainkan menggantikannya dengan objek yang lain yang sama sekali berbeda dengan apa yang diceritakan dan ada pula ilustrasi yang hanya bersifat dekoratif. Pemikiran - pemikiran Lala Bohang yang tertuang melalui pemilihan warna monochrome pada gambar-gambarnya menjadi sebuah keunikan yang menarik untuk diteliti. Penulis merasa tertantang untuk mengeksplorasi simbol - simbol visual, tehnik visual, dan juga konseptual desain yang ada. Seakan ilustrasi yang ada menambah kesan dramatis akan aneka peristiwa pengalaman hidup yang digambarkan melalui kumpulan puisi "The Book of Forbidden Feelings".

Seni ilustrasi untuk karya sastra berhubung dengan subyek yang bersifat subjektif-imajinatif seperti puisi dan prosa (cerpen, novel, esai). Seperti halnya dengan seni ilustrasi untuk karya ilmiah, seni ilustrasi untuk karya sastra juga harus mengacu pada teks yang didampinginya. Sang ilustrator harus menafsirkannya dengan memanfaatkan daya imajinasi yang bersifat subjektif-personal. Karya seni ilustrasi semacam ini "tidak berupaya menjelaskan" teks, tetapi untuk memberi pemaknaan visual yang diharapkan memperkuat "daya sentuh" teks kepada pembaca (Salam, 2017).

Dasar dari ilustrasi yang baik adalah; pengetahuan mendalam tentang prinsip yang relevan, teknik yang memadai, dan pengorganisasian terinci. Kata "ilustrasi" dalam konteks yang dibahas disini adalah komposisi gambar yang dimaksudkan sebagai penjelasan ataupun hiasan. Ilustrasi adalah sebuah representasi dari individualitas, dalam hitam dan putih, suasana, ataupun warna, tapi selalu dengan perangsangan yang menstimulasi pendambaan, menciptakan sebuah perasaan, mempengaruhi pendapat, atau memotivasi sebuah tindakan (Ross, 1963).

Dalam dunia seni, konsep kritik oleh para ahli seni masih sering diperdebatkan, sehingga tak pelak bila kemudian muncul berbagai konsep kritik dengan orientasi dan perspektif kajian yang berlainan. Agaknya perbedaan pandangan tentang kritik seni disebabkan oleh metode yang digunakan, dan setiap ahli seni merasa dirinya paling sah dalam melakukan aktifitas kritiknya sendiri. Menurut (Sudarmaji, 1979), kritik adalah komentar atau ulasan yang bersifat normatif terhadap sesuatu prestasi dan hal ikhwal dengan tujuan apresiasi. Bagi (Jerome, 1966) kritik seharusnya berupa aktivitas evaluasi yang memandang seni sebagai objek bagi pengalaman estetik. Kritik sebagai usaha pemahaman dan peningkatan 'kenikmatan dalam penghayatan karya seni. (Feldman \& Woods, 1981) memandang kritik seni sebagai studi rinci dan apresiasi dengan analisis cendekia atas karya seni yang disertai tafsir beserta alasan dari informasinya. Bagi (Dewey, 2005), kritik seni tidak perlu sampai pada keputusan nilai karena dengan deskripsi yang lengkap beserta pembahasannya sudha cukup untuk menangkap estetiknya. Berbeda dengan (Aschner, 1956) yang berpendapat, bahwa kritik sebagai aktifitas penilaian yang bisa ditransfer secara verbal, seperti memberikan alasan-alasan mengapa sebuah karya seni itu diterima atau ditolak. Dia juga berpendapat bahwa kegiatan kritik hendaknya melibatkan metode penelitian dan evaluasi yang bisa menjadi dasar bagi seseorang untuk mengkritik dalam upaya mengangkat karya seni ke jenjang yang tinggi.

\section{METODE PENELITIAN}

Penelitian ini menggunakan metode analisis isi (Content-Analysis) yakni sebuah metode penelitian yang fokusnya menganalisis suatu karya berupa tulisan (isi majalah, koran, pamflet, dsb). Rekaman verbal (pidato, lagu), atau karya visual (poster, kartun, atau lukisan). Pada penelitian ini mengkhususkan pada gambar ilustrasi yang ada pada buku kumpulan 
puisi "The Book of Forbidden Feelings". Tujuan dari metode analisis isi adalah untuk memberikan pengetahuan, wawasan, representasi fakta, dan panduan untuk bertindak. Dalam penelitian ini, metode analisis isi yang digunakan difokuskan pada meneliti karya komunikasi visual berupa gambar ilustrasi.

Sasaran penelitian ini adalah menganalisis kualitas artistik gambar - gambar ilustrasi yang ada pada buku kumpulan puisi "The Book of Forbidden Feelings" karya Lala Bohang dengan fokus pada bagaimana tiap gambar ilustrasi berperan sebagai visualisasi bagi teks puisi.

Penelitian ini dilakukan untuk memperoleh data tentang bagaimana kualitas artistik seni ilustrasi karya Lala Bohang pada buku puisi "The Book of Forbidden Feelings". Dengan demikian maka sasaran penelitian ini adalah; (1) Keefektifan komunikasi gambar ilustrasi karya Lala Bohang dalam mendampingi teks puisi pada buku "The Book of Forbidden Feelings". (2) Keartistikan wujud seni ilustrasi karya Lala Bohang pada buku "The Book of Forbidden Feelings".

Penelitian ini dilakukan dengan mengikuti prosedur penelitian Analisis-isi sebagaimana yang dikemukakan oleh (Elo \& Kyngäs, 2008) yang terdiri atas tiga tahap seperti pada gambar 04;

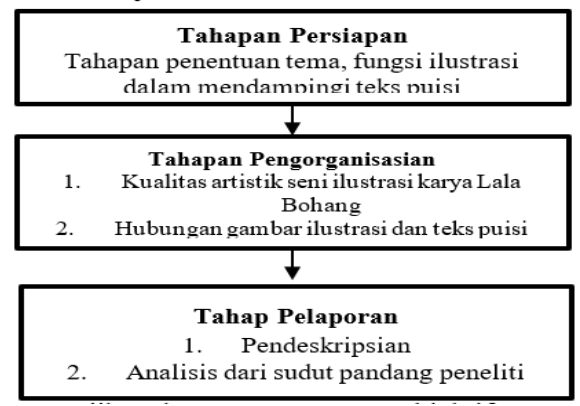

Gambar 04. Skema prosedur penelitian

\section{Sumber Data}

Sumber data dalam penelitian ini adalah naskah buku kumpulan puisi "The Book of Forbidden Feelings" terbitan PT. Gramedia Pustaka Utama (2017) karya Lala Bohang, beserta sumber - sumber kajian pustaka yang membahas teori tentang seni rupa, ilustrasi, dan kritik seni terhadap karya Lala Bohang, didukung dengan data tambahan berupa tulisan artikel yang membahas buku ini, dan juga dokumen resmi lainnya (Bohang, 2016)

\section{Teknik Pengumpulan Data}

Teknik pengumpulan data yang digunakan adalah studi dokumen dimana data yang dibutuhkan dalam penelitian ini sudah terkumpul secara otomatis pada sumber yaitu buku kumpulan puisi dan ilustrasi "The Book of Forbidden Feelings" karya Lala Bohang, yang dilakukan peneliti adalah memilih data tersebut. Dari 94 gambar ilustrasi dan 31 gambar ilustrasi diantaranya yang mendampingi teks dipilih 10 gambar ilustrasi sebagai sampel yang dianggap dapat mewakili berdasarkan kualitas artistiknya.

Peneliti menentukan bahwa hanya 10 sampel yang akan dipilih dikarenakan hampir semua gambar ilustrasi yang ada dalam buku tersebut memiliki karakteristik yang tidak jauh berbeda, menggunakan teknik dan warna yang sama, dan juga cenderung menampilkan karakter yang sama. Sepuluh gambar ilustrasi yang terpilih memiliki beberapa perbedaan karakteristik yang terdiri dari bentuk, komposisi, latar dan ruang pada halaman buku yang terpakai.

Teknik analisis data menggunakan pendekatan kritik seni yang dikemukakan oleh Edmund Burke Feldman. Teknik ini terdiri dari tiga tahapan, yaitu; (1) Deskripsi, adalah suatu proses pengumpulan data yang tersaji langsung kepada pengamat. Dalam tahap ini perlu dihindari penarikan kesimpulan yang melibatkan kesan pribadi yang sifatnya ilusif atau imajinatif. Peneliti dituntut untuk menyajikan keterangan secara objektif, yang bersumber pada ilustrasi yang diamati. (2) Analisis Formal, dalam tahap analisis formal, tugas peneliti adalah menguraikan mutu garis, bentuk, warna, pencahayaan dan penataan figur-figur, daerah warna, lokasi, serta ruang dalam ilustrasi. (3) Interpretasi, merupakan metode menganalisis suatu karya seni rupa dan desain dengan proses saat peneliti mengemukakan arti suatu karya setelah melakukan penyelidikan yang cermat. Kegiatan ini tidak dimaksudkan untuk 
menemukan nilai verbal yang setara dengan pengalaman yang diberikan karya seni.

\section{HASIL DAN PEMBAHASAN Hasil}

Pada BAB ini disajikan hasil penelitian yang diperoleh melalui studi dokumen sebagai instrumen dalam pengumpulan data sekaligus jawaban tentang rumusan masalah yang dikemukakan pada BAB sebelumnya.

\section{Keartistikan wujud seni ilustrasi karya Lala Bohang pada buku kumpulan puisi "The Book of Forbidden Feelings"}

Berikut ini adalah 10 gambar ilustrasi dan masing - masing teks puisinya karya Lala Bohang yang terpilih untuk mewakili 94 gambar ilustrasi lainnya dalam buku kumpulan puisi "The Book of Forbidden Feelings", diperoleh dari hasil studi dokumen koleksi buku pribadi penulis sebagai berikut:

\section{a. Gambar 05}

Berdasarkan hasil penelitian tampak bahwa pada gambar 05, menggambarkan enam ekor ubur - ubur yang memiliki bentuk tubuh berjenis medusa dengan sepasang kaki manusia diantara tentakelnya berenang bebas, ilustrator menggambarkan objek secara dinamis sehingga tampak seakan enam ubur ubur itu berenang dengan bebas dalam air dengan aksen gelembung udara disekitarnya dan menggunakan cat air dengan warna monochrome sebagai media. Menampakkan penggunaan teknik wet on wet yang menghasilkan beberapa bagian terlihat transparan dan juga sebagian lain opaque. Perpaduan komposisi dan peletakan objek terlihat indah dan dinamis memenuhi halaman buku. Dalam gambar ilustrasi ini dapat dilihat adanya personifikasi uang dilalukan sang ilustrator dengan menggambarkan sepasang kaki pada enam ekor ubur - ubur tersebut.

Dapat juga terlihat adanya penggayaan bentuk atau stilisasi yang identik dengan corak dekoratif yang digunakan. Ilustrator menyederhanakan bentuk dasar dari ubur ubur tanpa menghilangkan bentuk aslinya. Ilustrator juga menerapkan pengarahan perhatian yang langsung ditujukan kepada objek gambar ilustrasi dengan cara membiarkan latar dari gambar tetap bersih dan kosong dengan hanya menambahkan beberapa aksen gelembung udara.

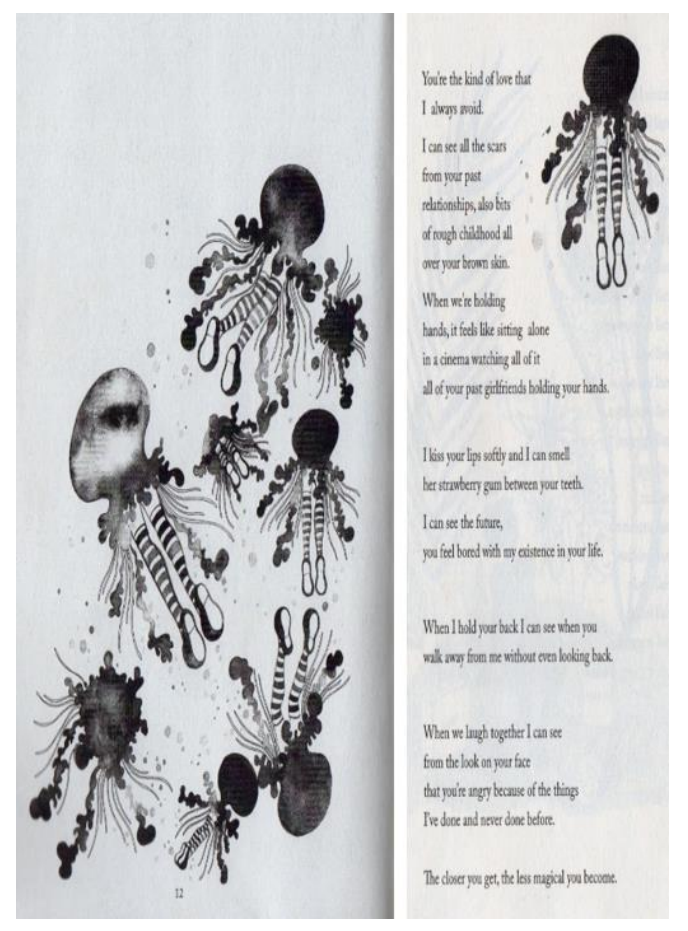

Gambar 05. Karya ilustrasi yang menggambarkan enam ekor ubur - ubur berkaki manusia dan teks puisi yang bercerita tentang tokoh utama yang mulai jenuh dengan kekasihnya.

b. Gambar 06

Pada gambar 06, ilustrator memilih menggambarkan siluet seorang gadis berukuran kecil dengan seekor siput sebagai hewan peliharaannya lengkap dengan mengenakan tali kekang untuk menjadi objeknya. Gadis itu duduk diatas rerumputan dengan latar belakang bebungan dan dedaunan yang jauh lebih besar ukurannya tidak seperti sebagaimana harusnya. Disekitarnya terdapat sebuah tas yang bertuliskan "Hope" (impian) dan alat penyiram tanaman dengan tulisan "Problem" (masalah). Dilihat dari bentuk dan proporsi dari gambar ilustrasi 02 dapat diketahui bahwa ilustrasi ini bercorak dekoratif dengan penyederhanaan bentuk yang tampak jelas pada gambar ini, ilustrator menggunakan garis tegas dalam menggambarkan objeknya, dan menggambarkan siluet seorang gadis sebagai focal point. Menggunakan cat air sebagai media dengan kombinasi teknik aquarel dan plakat. Sosok seorang gadis yang 


\section{imajinaasi}

berukuran lebih kecil dari bunga dan dedaunan yang. Ilustrator berhasil menggambarkan suasana taman kecil dengan bunga dan dedaunan besar yang sebagian diselimuti sarang laba - laba, seakan - akan si gadis telah masuk ke dunia lain dimana segala sesuatunya berukuran besar atau dia lah yang telah mengecil. Secara keseluruhan faktor keartistikan wujud gambar ilustrasi 02 terlihat indah dengan komposisi yang tampak indah dengan bentuk - bentuk sederhana yang ditampilkan.

Ilustrator mendramatisasikan bentuk objek - objek yang ada dalam gambar ilustrasi tersebut dengan memainkan ukuran daripada objek tersebut. Dan juga menggunakan siluet sebagai objek utamanya tentunya masih dengan penyederhanaan bentuk dari corak dekoratif yang digunakannya

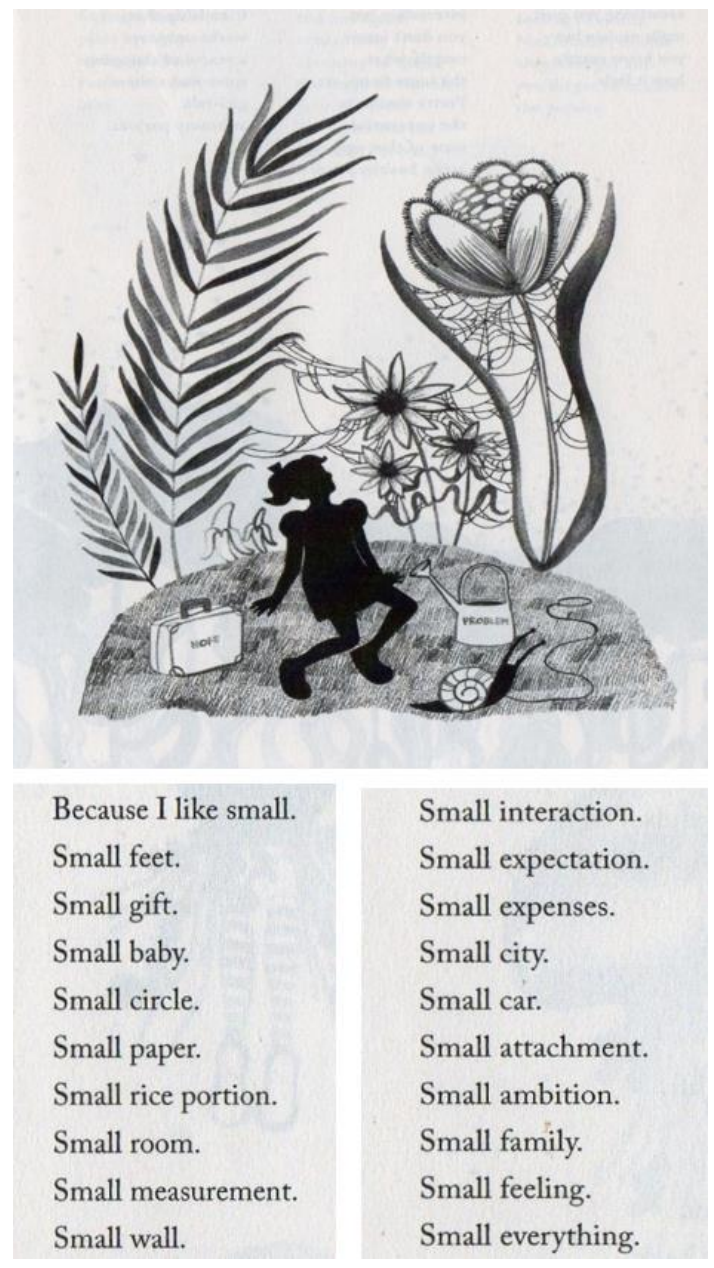

Gambar 06. Gambar ilustrasi yang menggambarkan siluet seorang gadis berukuran kecil duduk di taman bunga dan teks yang menuliskan tentang kesukaan tokoh utanga pada hal - hal kecil.

\section{c. Gambar 07}

Dalam ilustrasi itu juga digambarkan beberapa ornamen atau objek yang memenuhi latar tempat yang berupa kamar tidur. Selain tempat tidur ada pula tanaman, tas, cermin dan beberapa ornamen yang menghiasi dinding yang dibiarkan polos sementara lantai pada kamar tidur tersebut bermotif kotak - kotak seperti layaknya keramik dan langit - langit yang bermotif persegi panjang yang seakan merepresentasikan kayu dengan beberapa bagian diwarnai dengan cara plakat dan yang lainnya hampir transparan. Ilustrator tampak berhasil menggambarkan suasana kamar tidur dengan nilai - nilai keartistikannya dalam menggunakan penyederhanaan dari bentuk bentuk sebenarnya.

Gambar ilustrasi ini adalah salah satu dari beberapa yang memiliki interaksi dengan teks meskipun teks yang dipadukan dalam gambar tidak berhubungan dengan teks puisi yang didampingi namun tetap melengkapi gambar ilustrasi tersebut.

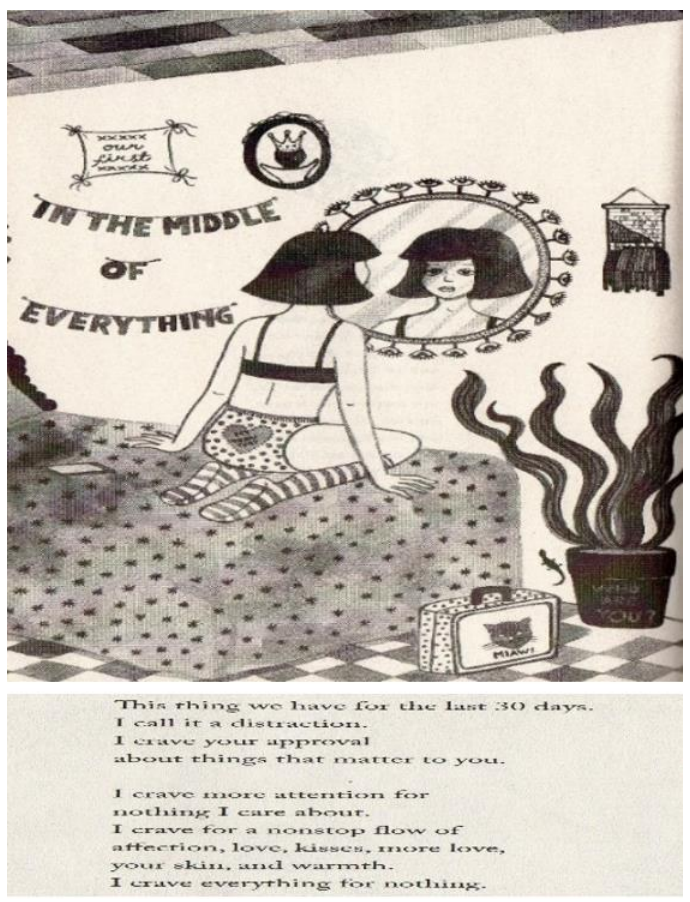

Gambar 07. Ilustrasi yang menggambarkan seorang gadis berambut pendek duduk di atas tempat tidur dan menatap cermin dan teks puisi yang menceritakan tokoh utama yang meratapi sesuatu. 


\section{d. Gambar 08}

Gambar 08 berupa gambar ilustrasi yang menggambarkan sosok wanita berambut pendek yang sedang duduk diatas tempat tidur tampak seakan sedang bersembunyi dibalik bantal menampakkan setengah dari wajahnya. Kamar tidur yang menjadi latar tempat gambar ilustrasi ini tampak berantakan dan tidak teratur dengan dinding yang penuh dengan poster dan ornamen lainnya sampai pada lantai di mana terdapat beberapa pot tanaman yang berisikan tanaman kaktus yang bertuliskan "pain" (rasa sakit), "lie" (kebohongan), "hope" (harapan) menampilkan interaksi gambar ilustrasi dengan teks

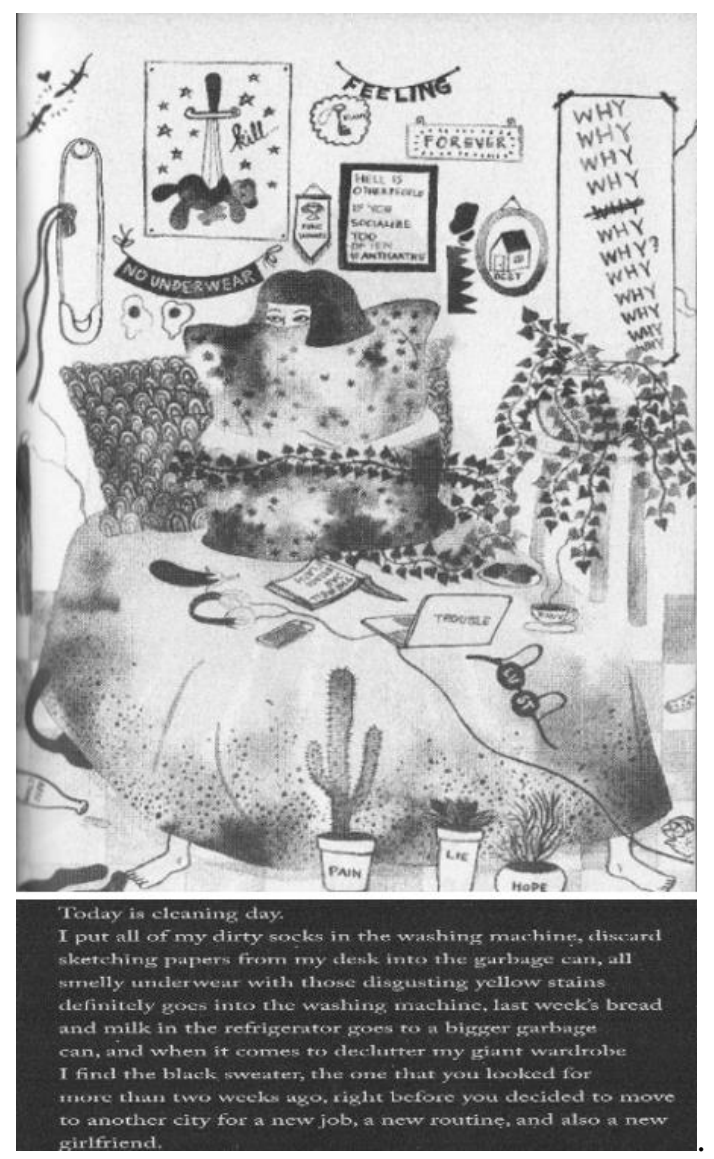

Gambar 08. Ilustrasi yang menggambarkan gadis berambut pendek bersembunyi dibalik bantal

diatas tempat tidur dan puisi yang menceritakan tentang kondisi kamar yang kotor.

Tampak pula sepasang kaki manusia yang muncul pada bagian bawah tempat tidur, pada gambar ilustrasi kali ini sang ilustrator melebih - lebihkan bentuk dengan cara menggambarkan jarak kaki yang jauh dari tubuh dan tidak sesuai standar anatomi. Namun secara keseluruhan ilustrator menggambarkan suasana kamar tidur yang berantakan dengan sangat baik. Secara keseluruhan mulai dari bentuk dan pewarnaan sampai dengan komposisi objek dan ornamen - ornamennya gambar ilustrasi ini tampak memenuhi unsur keartistikan wujud yang baik dan mampu menampilkan temanya dengan baik.

\section{e. Gambar 09}

Pada gambar 09, ilustrator menggambarkan 4 (empat) kepala wanita yang identik dan hanya memperlihatkan setengah dari wajah mereka yaitu dari kepala sampai ke mata, dua buah cangkir yang saling bertumpukan dengan dua buah piring sebagai alasnya, dan juga empat buah teko, salah satunya memiliki sepasang kaki manusia dengan kaus kaki bergaris. Tampak juga sekumpulan semut yang berjalan berbaris dan seekor kucing yang tertidur. Teko - teko pada gambar ilustrasi memiliki motif polka dot kecil dan beberapa bagian yang diwarnai dengan teknik wet on wet. Pada gambar ilustrasi ini ilustrator melalukan cukup banyak distorsi bentuk, seperti yang dapat dilihat 4 kepala wanita dengan ukuran yang berbeda namun tidak digambarkan tubuh ataupun tangan hanya sepasang kaki yang muncul dari bagian bawah salah satu teko. Namun ilustrator menggambarkan masing masing bentuk dari objek dan komponennya dengan indah.
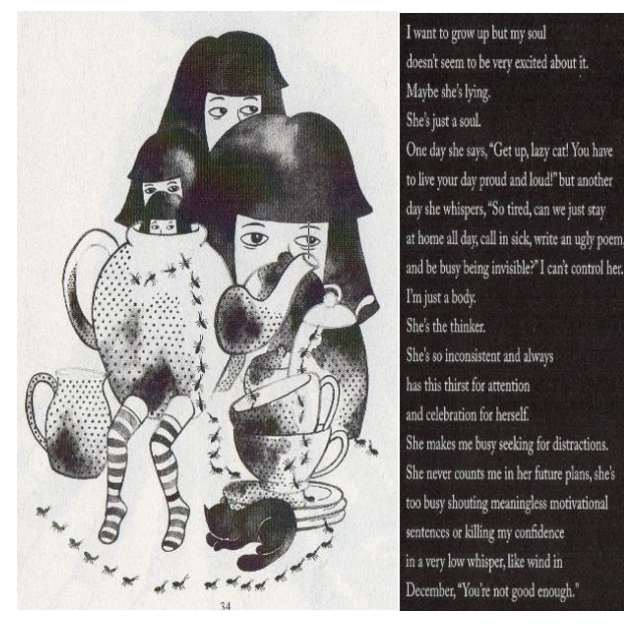

Gambar 09. Ilustrasi yang menampilkan tumpukan teko dan kepala manusia dan teks puisi yang menceritakan seseorang yang menganggap jiwa dan tubuhnya adalah dua orang berbeda. 


\section{imajinaasi}

Ilustrator menampilkan simbol dengan menggambarkan semut yang berbaris dengan rapih mengitari objek - objek lainnya pada gambar ilustrasi tersebut. Dramatisasi pada ukuran objek juga terlihat jelas sebagaimana objek - objek yang ditampilkan pada gambar ilustrasi tidak sesuai dengan yang ada sewajarnya.

\section{f. Gambar 10}

Pada gambar 10, berbeda dengan beberapa gambar - gambar ilustrasi sebelumnya pada gambar ilustrasi ini hanya digambarkan satu objek saja. Terlihat seperti figur siluet seorang manusia dengan 8 tangkai bunga yang tumbuh dikepalanya, sang ilustrator tidak menggambarkan bentuk tubuh manusia dengan lengkap sesuai dengan alam namum hanya menggambarkan bentuk siluetnya dari kepala sampai pada bahu dan juga menggabungkannya dengan tangkai tangkai bunga yang ada. Seakan menampilkan 8 tangkai bunga dengan akar yang membentuk siluet manusia. Secara keseluruhan ilustrator menggambarkan objek dengan baik dan sederhana berbeda dengan gambar - gambar ilustrasi sebelumnya yang dipenuhi ornamen ornamen lain.

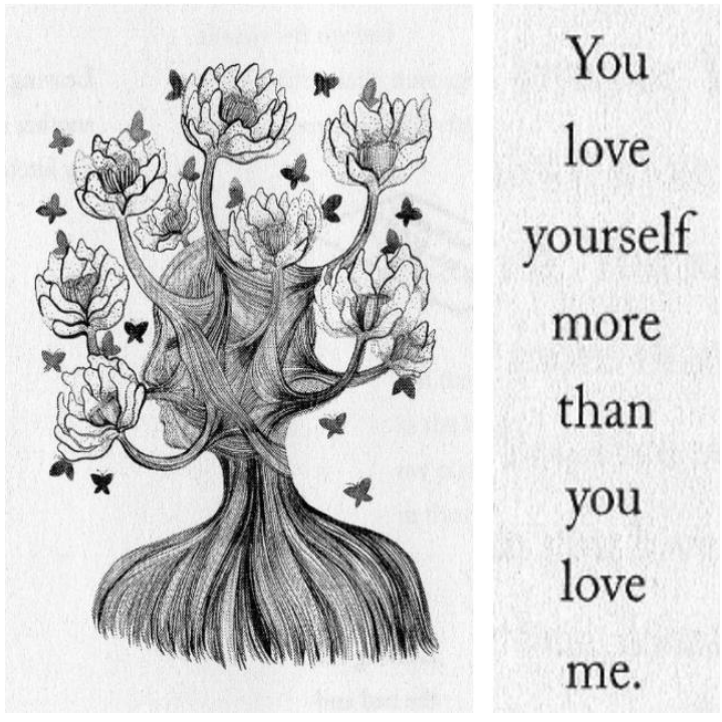

Gambar 10. Ilustrasi yang menggambarkan bentuk siluet tubuh manusia yang terdiri dari akar tumbuhan dan teks yang menceritakan tentang seseorang yang lebih mencintai dirinya sendiri.

\section{g. Gambar 11}

Pada gambar 11, berdasarkan hasil penelitian gambar ilustrasi inilah yang memiliki distorsi atau perubahan bentuk dari bentuk alam yang paling tampak jelas dibanding gambar - gambar sebelumnya. Ditampilkan berbalik dari ilustrasi sebelumnya dimana ilustrator menggambarkan objek dengan cat air hitam pada media kertas berwarna putih, kali ini objek digambarkan berwarna putih dengan latar hitam.

Menampilkan sebuah objek yang tampak seperti sekuntum bunga besar dengan banyak kepala wanita berambut pendek yang identik digambarkan hampir pada setiap gambar ilustrasinya muncul ada cabang cabang yang keluar dari tengah bunga yang sedang mekar tersebut. Ilustrator menggambarkan lekukan - lekukan cabang dan bunga - bunga kecil dengan indah sehingga menampilkan kesan gerakan yang dinamis dan lembut.
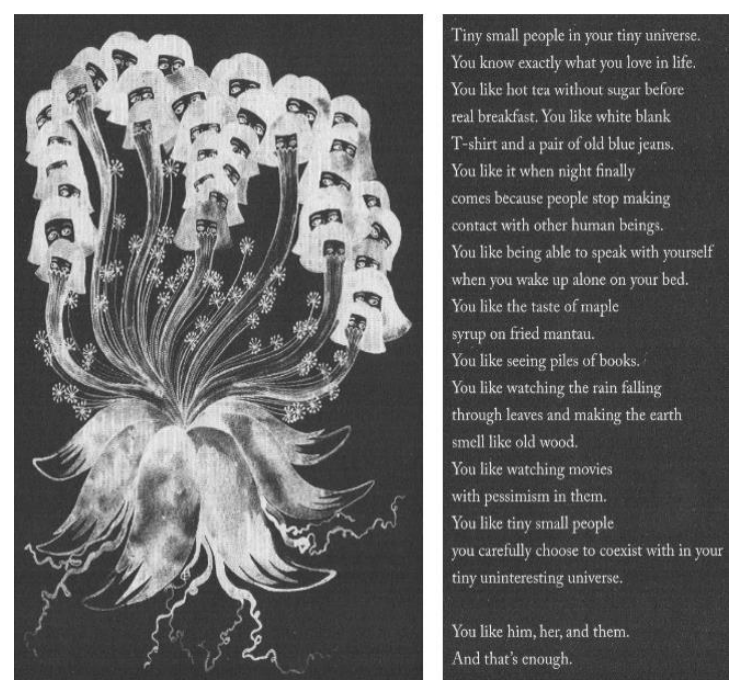

Gambar 11. Illustrasi yang menggambarkan sebuah bunga bercabang kepala manusia dan teks puisi yang bercerita tentang seseorang yang sangat mengenal dirinya sendiri.

Berdasarkan pengamatan peneliti gambar ilustrasi ini yang paling terlihat tema surealistiknya dan ilustrator juga melakukan rekacipta karena seperti yang diketahui tidak ada makhluk hidup yang terdiri dari perpaduan tumbuhan dan kepala manusia dalam dunia nyata. Seperti pada beberapa ilustrasi 
sebelumnya ilustrator juga mengalihkan perhatian langsung pada objek gambar yang terlihat kontras digambarkan pada kertas hitam.

Pada gambar ilustrasi ini ilustrator mengalihkan perhatian pembaca langsung kepada objek karena tidak menambahkan elemen apapun disekitarnya. Objek berupa hasil dari penggayaan bentuk dari perpaduan antara tumbuhan dan bentuk siluet manusia.

\section{h. Gambar 12}

Dalam gambar 12, ilustrator kembali menampilkan sosok gadis berambut pendek pada ilustrasi 08 ini. Dia digambarkan mengenakan sweater rajut dengan leher turtle neck yang menutupi wajahnya sampai bagian bawah mata, ilustrator menggambarkan tekstur rajut pada sweater dengan sederhana melalui teknik pewarnaan namun tetap menampilkannya dengan sangat baik. Aksen distorsi atau pengubahan bentuk terlihat pada jumlah tangan yang dilebih - lebihkan serta ukuran panjangnya.

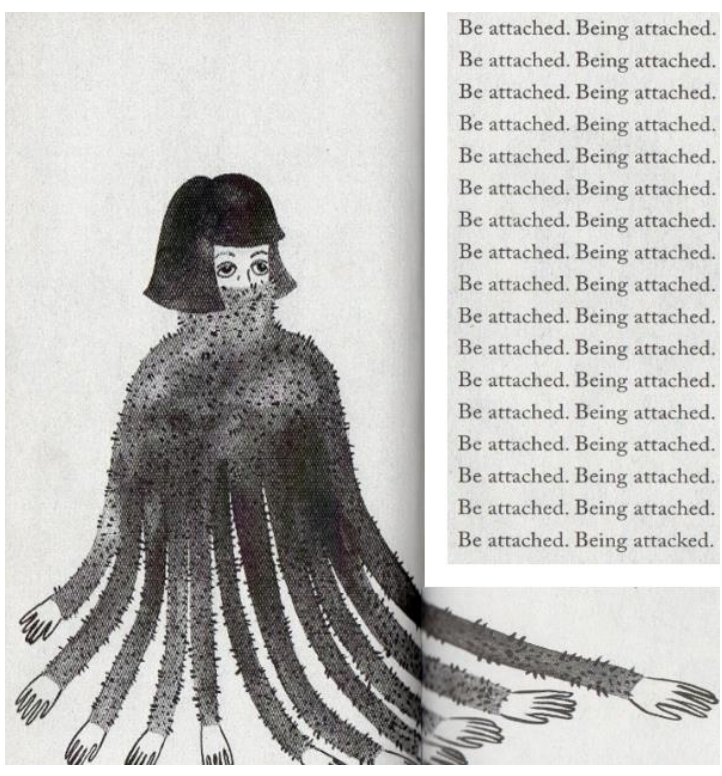

Gambar 12. Ilustrasi yang menggambarkan seorang gadis dengan tangan yang banyak dan teks puisi yang menceritakan tentang ketergantungan.

Tema surealistik tampak ditampilkan dengan corak dekoratif yang khas dalam ilustrasi ini dimana ilustrator menggambarkan 11 pasang tangan yang panjang pada sosok gadis berambut pendek yang hampir menjadi objek pada setiap gambar ilustrasi dalam buku. Ilustrator juga mengalihkan perhatian pembaca langsung pada objeknya dengan cara tidak menambahkan latar pada gamabar ilustrasi ini.

\section{i. Gambar 13}

Gambar ilustrasi menampilkan gadis berambut pendek yang sama seperti pada gambar - gambar ilustrasi sebelumnya, ilustrator menggambarkan gadis tersebut mengenakan kemeja putih sedang duduk dan menikmati makanan cepat saji didalam sebuah ruangan yang dindingnya dihiasi bermacam macam makanan cepat saji. Keseluruhan suasana ruang yang dinamakan "snack room" ini terlihat ramai tidak lupa ilustrator menampilkan beberapa objek yang dilebih lebihkan ukuran dalam gambar dibanding ukuran sebenarnya. Keseluruhan gambar ilustrasi terlihat menarik dan seimbang komposisinya memenuhi halaman buku.

Dalam gambar ilustrasi ini terlihat banyak disisipkan simbol dan teks didalamnya yang menghasilkan gambar ilustrasi sangat mudah dimengerti oleh pembaca dan akan langsung menangkap ide yang ingin disampaikan sang ilustraor. Masih dengan corak dekoratif dan stilisasi penyederhanaan bentuk - bentuk objek yang tidak memiliki sisi terang gelap.

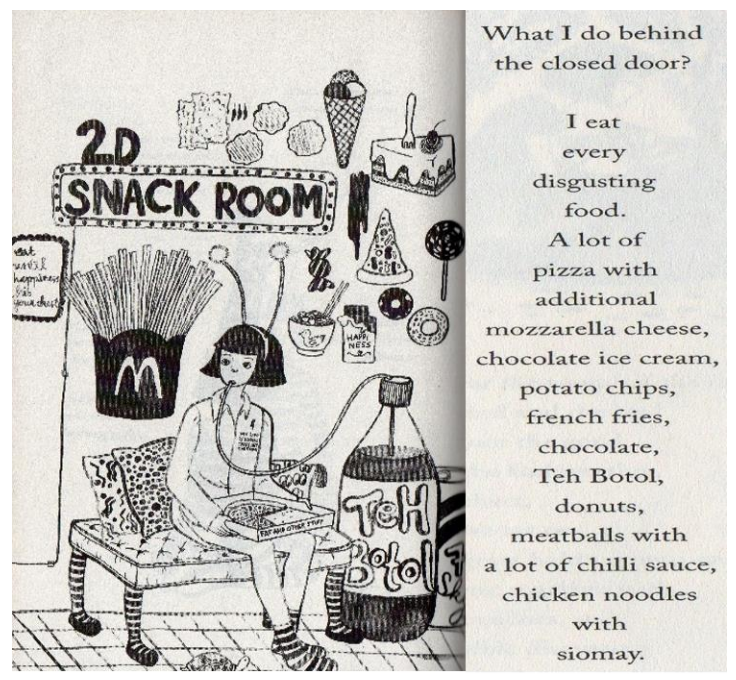

Gambar 13. Ilustrasi yang menggambarkan ruangan penuh makanan dan teks puisi yang menceritakan tentang ruang dimana tokoh utama mengkonsumsi semua makanan yang dia sukai. 


\section{j. Gambar 14}

Dalam gambar 14, ilustrasi menempati dua bagian dari halaman buku dengan latar bukit bebatuan yang diselimuti kabut dan seorang gadis duduk bersandar pada salah satu bukit sambil bermain seni tangan menggunakan benang dengan seekor gurita diatas kepalanya. Menilai secara keseluruhan faktor keartistikan wujudnya pada gambar ilustrasi ini ilustrator berhasil menampilkan kesan lembut dan suasana tenang dengan indah dan harmonis dengan corak dekoratif yang ditampilkan dengan bentuk datar sederhana.

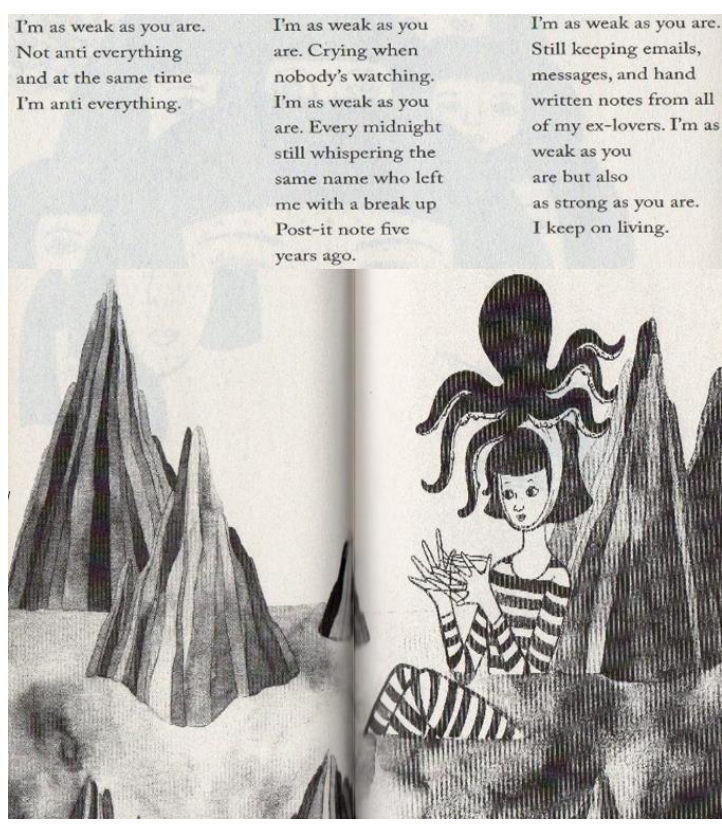

Gambar 14. Ilustrasi yang menggambarkan bukit bukit batu yang diselimuti kabut dan dan teks puisi yang menceritakan tokoh utama yang menganggap dirinya lemah.

Ilustrator menggambarkan latar pemandangan pegunungan dengan menyederhanakan bentuknya dan juga kesan embun dibawahnya. Kembali menampilkan sosok gadis berambut pendek pada ilustrasi ini yang terlihat mengenakan pakaian bergaris. Pada sebuah kesempatan tanya jawab yang dihadiri peneliti sang ilustrator mengutarakan bahwa ada makna dibalik pakaian bergaris yang dikenakan objek karyanya itu. Arti dari pakaian bergaris itu adalah tubuh yang memenjarakan jiwa seperti yang dikenal masyarakat secara luas pakaian bergaris adalah simbol dari seorang narapidana yang dipenjarakan. Sedikit tema surealis juga ditampilkan dalam gambar ilustrasi ini dengan cara menggambarkan gurita yang berada diatas kepala gadis tersebut lengkap dengan dramatisasi ukuran objek - objek yang digambarkan.

\section{Keefektifan komunikasi gambar ilustrasi karya Lala Bohang dalam mendampingi teks puisi pada buku "The Book of Forbidden Feelings"}

Berikut ini adalah pemaparan hasil analisis penulis mengenai tingkat keefektifan komunikasi 10 gambar ilustrasi yang terpilih dalam mendampingi teks puisi pada buku "The Book of Forbidden Feelings" sebagai berikut:.

\section{a. Gambar 05}

Pada gambar ilustrasi digambarkan enam ekor ubur - ubur yang memiliki bentuk tubuh berjenis medusa dengan sepasang kaki manusia diantara tentakelnya berenang bebas, ilustrator menggambarkan objek secara dinamis sehingga tampak seakan enam ubur ubur itu berenang dengan bebas dalam air dengan aksen gelembung udara disekitarnya.

Teks menceritakan tentang seorang tokoh utama dituliskan sebagai " $P$ " (aku/ saya) yang mencintai seseorang namun disaat yang sama merasa ingin menghindarinya. Bait pertama menceritakan bagaimana tokoh utama merasa sendiri meskipun sedang bergandengan tangan dengan kekasihnya. Pada bait kedua dan ketiga menceritakan tokoh utama yang seakan bisa melihat masa depan dan menebak bahwa kekasihnya akan merasa bosan dan meninggalkannya. Dan akhirnya pada dua bait terakhir dituliskan bahwa tokoh utama merasa semakin lama dia mengenal kekasihnya maka semakin memudarlah perasaannya.

Jika diperhatikan sekilas tidak terlihat adanya hubungan antara gambar ilustrasi dengan teks puisi, akan tetapi jika diperhatikan lebih mendalam ilustrator menyampaikan perasaan jenuh dan keinginan untuk bebas dari tokoh utama pada teks puisi. Keinginannya untuk pergi meninggalkan rasa jenuh dan rasa tidak aman yang membayang-bayanginya saat sedang bersama kekasihnya, bebas seperti sekelompok ubur-ubur yang berenang di lautan. Kesimpulannya tingkat keefektifan 
komunikasi antara gambar ilustrasi dan teks puisi kurang tampak secara sekilas namun masih dapat ditemukan kaitannya jika lebih dipahami.

\section{b. Gambar 06}

Dalam ilustrasi pada gambar 06 ilustrator menggambarkan siluet seorang gadis berukuran kecil dengan seekor siput sebagai hewan peliharaannya lengkap dengan mengenakan tali kekang untuk menjadi objeknya. Gadis itu duduk diatas rerumputan dengan latar belakang bebungaan dan dedaunan yang jauh lebih besar ukurannya tidak seperti sebagaimana harusnya. Disekitarnya terdapat sebuah tas yang bertuliskan "Hope" (impian) dan alat penyiram tanaman dengan tulisan "Problem" (masalah).

Pada teks puisi penulis mengangkat tema "kecil" dengan menyebutkan hal - hal yang dia sukai dalam ukuran kecil dan mengawali puisinya dengan kata "Because I like small" yang berarti "Karena saya suka kecil". Penulis menyebutkan hal - hal seperti benda, kata kerja, dan kata sifat. Sebagai contoh "Small gift" (hadiah kecil), "Small room" (ruang kecil), "Small expenses" (pengeluaran kecil), "Small ambition" (ambisi kecil), dan masih banyak lagi.

Hubungan antara teks puisi dan gambar ilustrasi dapat dilihat dengan jelas karena keduanya mengangkat kata "kecil" sebagai temanya. Namun, ilustrator tidak menggambarkan satupun hal - hal yang dia sebutkan dalam teks puisinya begitu pula yang terlihat pada gambar ilustrasi tidak terdapat objek yang merepresentasikan benda - benda yang disebutkan dalan teks secara langsung. Dapat dikatakan keefektifan komunikasi antara gambar ilustrasi dan teks puisi tampak jelas meskipun ilustrator tidak menggambarkan apa yang ada pada teks secara harafiah melainkan hanya sebatas pada temanya saja. Sama halnya dengan tulisan "Hope" dan "Problem" pada ilustrasi tidak mencerminkan makna yang ada pada teks, namun dapat diartikan pada ilustrasi itu sendiri yang menceritakan seorang gadis yang datang dengan membawa impiannya namun menghapi masalah yang terus bertumbuh seperti tanaman yang disirami air.

\section{c. Gambar 07}

Gambar ilustrasi pada gambar 07 menggambarkan seorang wanita sedang duduk diatas tempat tidur sambil menatap dirinya di cermin di dalam sebuah kamar tidur.

Teks menceritakan tentang seorang tokoh utama yang sangat ingin diakui oleh kekasihnya dan menginginkan semua yang bisa dia berikan padanya, namun tokoh utama juga merasa bahwa semua itu hanyalah gangguan sementara.

Hubungan antara gambar ilustrasi dan teks puisi dapat dilihat pada sosok wanita yang menjadi objek pada ilustrasi sebagai tokoh utama pada teks. Sang tokoh utama menatap dirinya sendiri di cermin dengan tatapan lurus tak berekspresi seakan sedang berfikir keras. Sesuai dengan teks dimana sang tokoh utama menyadari bahwa sikapnya yang terobsesi pada pengakuan kekasihnya hanyalah sebuah gangguan yang telah berlangsung cukup lama.

\section{d. Gambar 08}

Gambar ilustrasi menampilkan sosok wanita berambut pendek yang sedang duduk di atas tempat tidur tampak seakan sedang bersembunyi di balik bantal menampakkan setengah dari wajahnya. Kamar tidur yang menjadi latar tempat gambar ilustrasi ini tampak berantakan dan tidak teratur dengan dinding yang penuh dengan poster dan ornamen lainnya sampai pada lantai dimana terdapat beberapa pot tanaman yang berisikan tanaman kaktus yang bertuliskan "pain" (rasa sakit), "lie" (kebohongan), "hope" (harapan).

Teks menceritakan tentang hari membersihkan, dimana sang tokoh utama membersihkan kamarnya dengan meletakkan kaus kaki kedalam mesin cuci, membuang kertas - kertas sketch, mengumpulkan pakaian kotor sampai akhirnya menemukan sweater hitam yang mengingatkannya dengan mantan kekasihnya yang pergi mumulai hidup baru.

Berdasarkan hasil penelitian hubungan komunikatif antara gambar ilustrasi dan teks puisi cukup tampak dari bagaimana ilustrator menampilkan suasana kamar tidur yang berantakan dan tak beraturan seperti pada teks 
yang menceritakan seorang tokoh utama yang sedang membersihkan kamarnya, namun ilustrator tidak menampilkan perasaan tokoh utama yang mengenang mantan kekasihnya. Maka dapat disimpulkan bahwa tingkat keefektifan komunikasi antara gambar ilustrasi dan gambar ilustrasi cukup baik namun tidak sepenuhnya menggambarkan keadaan dalam teks.

\section{e. Gambar 09}

Pada gambar ilustrasi, ilustrator menggambarkan 4 (empat) kepala wanita yang identik dan hanya memperlihatkan setengah dari wajah mereka yaitu dari kepala sampai ke mata, dua buah cangkir yang saling bertumpukan dengan dua buah piring sebagai alasnya, dan juga empat buat teko, salah satunya memiliki sepasang kaki manusia dengan kaus kaki bergaris. Tampak juga sekumpulan semut yang berjalan berbaris dan seekor kucing yang tertidur.

Sedangkan pada teks diceritakan seorang tokoh utama yang tubuh dan jiwanya dituliskan seakan mereka masing - masing adalah dua orang berbeda. Dimana tubuh ingin menjadi dewasa sementara jiwa tidak, terkadang jiwa berkata "bangunlah dan jalani hidupmu" dan kadang pula "bisa kah kita tinggal dirumah saja hari ini?" sementara tubuh bingung karena tidak dapat mengendalikannya menganggap dirinya hanyalah sebatas tubuh dan jiwa lah yang berfikir dan sedikit egois.

Dilihat secara langsung tidak tampak ada hubungan jelas antara ilustrasi yang menggambarkan teko - teko dengan banyak kepala, namun dapat dikaitkan dengan keegoisan jiwa dibanding tubuh dan bagaimana sang tokoh utama menganggap dirinya seakan terdiri dari beberapa individu yang berdeda.

\section{f. Gambar 10}

Pada gambar ilustrasi ini hanya digambarkan satu objek saja. Terlihat seperti figur siluet seorang manusia dengan 8 tangkai bunga yang tumbuh dikepalanya, sang ilustrator tidak menggambarkan bentuk tubuh manusia dengan lengkap sesuai dengan alam namum hanya menggambarkan bentuk siluetnya dari kepala sampai pada bahu dan juga menggabungkannya dengan tangkai tangkai bunga yang ada. Seakan menampilkan 8 tangkai bunga dengan akar yang membentuk siluet manusia.

Pada teks dituliskan satu kalimat pendek yaitu "you love yoursef more than you love me." Yang berarti "kamu mencintai dirimu sendiri lebih dari kamu mencintaiku" pada pasangan teks dan ilustrasi tidak tampak adanya relasi antara keduanya maka disimpulkan bahwa ilustrasi hanya bertujuan untuk memenuni fungsi ilustrasi sebagai elemen dekoratif untuk teks.

\section{g. Gambar 11}

Gamabar ilustrasi inilah yang memiliki distorsi atau perubahan bentuk dari bentuk alam yang paling tampak jelas dibanding gambar - gambar sebelumnya. Ditampilkan berbalik dari ilustrasi sebelumnya dimana ilustrator menggambarkan objek dengan cat air hitam pada media kertas berwarna putih, kali ini objek digambarkan berwarna putih dengan latar hitam. Menampilkan sebuah objek yang tampak seperti sekuntum bunga besar dengan banyak kepala wanita berambut pendek yang identik digambarkan hampir pada setiap gambar ilustrasinya muncul ada cabang cabang yang keluar dari tengah bunga yang sedang mekar tersebut.

Teks menceritakan bagaimana seseorang sangat mengetahui dirinya sendiri, mengetahui apa yang dia sukai dan cintai di dunia. Mulai dari hal - hal kecil seperti kebiasaan minum teh sebelum sarapan dan mengenakan baju berwarna putih yang dipadukan dengan celana jeans biru dan sebagainya.

Sama seperti pada pembahasan sebelumnya, pada panduan antara ilustrasi dan teks tidak tampak adanya hubungan dalam pemaknaannya maka tingkat keefektifan komunikasi antara gambar ilustrasi dan teks puisi dinyatakan tidak terpenuhi.

\section{h. Gambar 12}

Ilustrator kembali menampilkan sosok gadis berambut pendek pada ilustrasi ini. Dia 
digambarkan mengenakan sweater rajut dengan leher turtle neck yang menutupi wajahnya sampai bagian bawah mata

Teks hanya tertulis satu kalimat yang diulang - ulang yaitu "be attach." dan "being attach" yang menceritakan tentang keterikatan

Keefektifan komunikasi antara gambar ilustrasi dan teks puisi kurang tampak karena ilustrator tidak menggambarkan langsung seperti apa keterikatan yang dia maksud dalam teks. Namun dapat diartikan sebagai satu tangan saling terikat satu sama lainnya.

\section{i. Gambar 13}

Gambar ilustrasi menampilkan gadis berambut pendek yang sama seperti pada gambar - gambar ilustrasi sebelumnya, ilustrator menggambarkan gadis tersebut mengenakan kemeja putih sedang duduk dan menikmati makanan cepat saji didalam sebuah ruangan yang dindingnya dihiasi bermacam macam makanan cepat saji.

Teks menceritakan apa yang tokoh utama lakukan dibalik pintu yang tertutup. Dia akan memakan semua makanan cepat saji, pizza yang banyak dengan tambahan keju, ice cream, kentang goreng, dan masih banyak lagi.

Dengan perpaduan antara ilustrasi dan teks dapat dilihat nilai komunikatif yang jelas. Ilustrator menggambarkan setiap jenis makanan yang disebutkan dalam teks kedalam ilustrasinya lengkap dengan seorang tokoh utama yang tengah menikmati semua makanan kesukaannya dalam ruang yang dia namai "snack room". Ilustrator menampilkan isi teks puisi sesuai dengan apa yang dituliskan.

\section{j. Gambar 14}

Ilustrasi pada gambar 14 menempati dua bagian dari halaman buku, dengan latar bukit bebatuan yang diselimuti kabut dan seorang gadis duduk bersandar pada salah satu bukit sambil bermain seni tangan menggunakan benang dengan seekor gurita diatas kepalanya.

Sedangkan pada teks menceritakan tokoh utama yang menganggap dirinya lemah karena masih menangis ketika tidak ada orang lain yang melihatnya dan karena dia masih terbayang - bayang kenangan mantan kekasihnya tapi pada waktu yang sama merasa kuat karena tetap mencintainya.

Tampak tingkat keefektifan komunikasi antara gambar ilustrasi dan teks puisi hanya sebatas tema dan suasana, teks menyampaikan suasana tenang dan perasaan pasti seseorang yang didukung dengan suasana tenang dan harmonis yang sama ditampilkan pada ilustrasi tanpa harus menggambarkan cerita pada teks secara harafiah.

\section{Pembahasan}

Buku kumpulan puisi "The Book of Forbidden Feelings" terdiri dari 152 halaman yang mengandung 31 halaman teks puisi dan 94 ilustrasi bercorak dekoratif. Dari 31 teks puisi yang didampingi gambar ilustrasi telah dipilih 10 yang dianggap dapat mewakili sebagai hasil penelitian. Berikut ini adalah pembahasan mengenai kualitas artistik karya ilustrasi Lala Bohang sesuai dengan yang sudah dipaparkan pada bagian hasil;

\section{Keartistikan wujud seni ilustrasi karya Lala Bohang pada buku kumpulan puisi "The Book of Forbidden Feelings"}

\section{Semua gambar ilustrasi pada buku} "The Book of Forbidden Feelings" digambarkan dengan tema warna monochrome yang sama dengan corak dekoratif yang diwujudkan dengan bahan cat air pada media kertas, ada yang bersifat naratif dan juga sebagai ornamen dekorasi untuk teks yang didampinginya. Secara keseluruhan ilustrasi karya Lala Bohang pada buku ini terlihat indah, dinamis, dan harmonis mengikuti tema. Dengan memunculkan tokoh yang sama dalam hampir semua gambar ilustrasinya yaitu si gadis berambut pendek yang identik dengan pakaian bergaris.

Ilustrator menggunakan beberapa jenis pendekatan untuk mewujudkan idenya dalam bentuk visual yang bernilai artistik seperti, personifikasi hewan dan benda yang ditampilkan pada gambar 05 menampilkan ubur - ubur berkaki manusia dan juga pada gambar 13 menampilkan sebuah kursi dengan 
empat pasang kaki. Mendramatisasikan bentuk dan ukuran objek yang digambarkannya pada hampir semu karya - karya ilustrasi dalam buku. Penggambaran objek dalam bentuk siluet manusia, pengalihan perhatian pembaca yang langsung ditujukan pada objek dalam gambar dengan cara membiarkan latar polos dan sederhana. Penggunaan simbol yang terlihat jelas pada gambar 13 dan juga dilengkapi dengan interaksi teks dalam gambar. Penggayaan bentuk adalah pendekatan yang paling terlihat dan digunakan paling banyak pada objek - objek dalam gambar ilustrasi yang kebanyakan dilakukan dengan penyederhanaan bentuk, ilustrator juga melakukan rekacipta pada beberapa karyanya menggabungkan benda dan bagian tubuh manusia, juga antara tumbuhan dan bagian tubuh manusia yang terkesan bertema surealis.

Semua pendekatan tersebut dieksekusi dengan baik sehingga pembaca dapat memahami ide yang terkandung didalamnya meskipun beberapa objek tidak digambarkan dengan bentuk aslinya sesuai dengan yang ada di alam. Ilustrator juga menggambarkan karya - karya ilustrasi sesuai dengan style atau gaya unik miliknya sendiri secara konsisten dalam semua karyanya yang ada dalam buku.

Kesimpulannya karya - karya ilustrasi Lala Bohang memiliki nilai - nilai keartistikan wujud yang baik dan dengan berhasil menampilkan idenya dalam bentuk - bentuk visual yang orisinil.

\section{Keefektifan komunikasi gambar ilustrasi karya Lala Bohang dalam mendampingi teks puisi pada buku "The Book of Forbidden Feelings"}

Untuk memenuhi fungsi ilustrasi dalam mendampingi karya sastra yaitu untuk menceritakan secara jelas suatu peristiwa, dongeng, atau roman dalam bentuk rangkaian gambar yang sesuai dengan teks.

Sesuai dengan yang dinyatakan Zeegen bahwa, sebuah ilustrasi dinyatakan tidak berhasil memenuhi fungsinya bila ilustrasi tersebut hanya sebatas ornamen pengisi halaman yang meskipun terlihat bagus tetapi tetap dinyatakan gagal dalam mengkomunikasikan subjeknya. Ilustrasi berfungsi mengajak orang - orang untuk berfikir, untuk menggambar lebih dari yang terlihat pada teks dan menciptakan pemahaman yang lebih luas dan mendalam tentang subjeknya. Ilustrasi yang baik bagaikan cerita atau narasi yang mengharuskan pembacanya terlibat secara aktif untuk dapat memahami pesan yang terkandung secara sepenuhnya.

Hasil penelitian menunjukkan bahwa dari 10 gambar ilustrasi yang terpilih, 6 diantaranya tidak menyampaikan isi teks sesuai yang tertulis di dalamnya secara harafiah dan dianggap tidak memenuhi fungsinya sebagai ilustrasi yang bersifat komunikatif terhadap teks yang didampinginya, melainkan hanya sebatas tema dan suasananya yang berkaitan. Sementara 4 lainnya menampilkan apa yang tertulis di dalam teks sebagaimana adanya. 6 gambar ilustrasi yang tidak menampilkan isi teks sesuai dengan yang tertulis contohnya seperti pada gambar 07 yang menggambarkan gadis berambut pendek sedang duduk di atas tempat tidurnya sambil menatap lurus ke cermin seakan sedang merenungi sesuatu, sementara teks yang didampingi menceritakan tentang tokoh utama yang menyadari bahwa dirinya telah larut dalam gangguan yang tidak menghasilkan apa - apa. Ilustrator tidak menggambarkan secara harafiah sang tokoh utama dan perasaan - perasaan yang sedang dirasakannya tapi dalam gambar ilustrasi tersebut pembaca dapat mengerti situasi yang sedang dialami tokoh utama dalam teks dan gambar. Ilustrator menggambarkan perasaan gundah yang dirasakan tokoh utama dengan baik dan berhasil disampaikan kepada pembaca.

Sementara 4 ilustrasi lainnya yang menampilkan objek sesuai dengan isi teks seperti pada gambar 13 yang menampilkan gadis berambut pendek yang sama duduk disebuah kusri menikmati makanan dan minuman cepat saji dalam ruangan yang dinamakan "2D Snack Room" yang dihiasi dengan berbagai macam makanan. Sesuai dengan apa yang tertulis dalam teks dimana seorang tokoh utama bersembunyi di balik ruang tertutup dan mengkonsumsi beragam jenis makanan cepat saji secara sembunyi sembunyi untuk memuaskan dirinya. 
Teks menyebutkan jenis makanan seperti "pizza, ice cream, french fries, teh botol" dan masih banyak lainnya yang secara langsung diterjemahkan dalam bentuk visual dalam gambar ilustrasi dengan penggayaan bentuk dan dramatisasi ukuran. Gambar ilustrasi tersebut juga dilengkapi dengan simbol - simbol merek makanan dan minuman yang sangat dikenal masyarakat luas. Dan juga terdapat interaksi teks untuk memperjelas ilustrasi seperti pada nama ruangan dimana gadis berambut pendek itu digambarkan. Semua itu membantu pembaca untuk memahami isi teks dan kandungan ide yang ingin disampaikan ilustrator dengan lebih cepat dan jelas

\section{SIMPULAN DAN SARAN}

Pada penelitian ini terdapat 31 gambar ilustrasi karya Lala Bohang yang mendampingi teks puisi dalam buku kumpulan puisi "The Book of Forbidden Feelings" dan telah terpilih 10 gambar ilustrasi sebagai sampel yang dianggap dapat mewakili berdasarkan kualitas artistiknya. Sepuluh gambar ilustrasi yang terpilih memiliki beberapa perbedaan karakteristik yang terdiri dari bentuk, komposisi, latar dan ruang pada halaman buku yang terpakai. Karya tersebut dibuat menggunakan cat air dituangkan di atas kertas dengan penggunaan warna monochrome. Setiap gambar ilustrasi memiliki tema dan suasana yang berbeda sesuai dengan teks puisi yang didampinginya. Berdasarkan hasil penelitian, maka dapat ditarik kesimpulan sebagai berikut:

1. Karya ilustrasi ditampilkan dengan corak dekoratif dan menggunakan pemilihan warna seragam yang menggambarkan objek seperti manusia, hewan, tumbuhan, benda, dan ruang dengan keartistikan wujud yang baik keseluruhannya dengan komposisi yang harmonis dan bentuk bentuk yang sederhana namun tetap kreatif dan dinamis.

2. Tingkat keefektifan komunikasi gambar ilustrasi karya Lala Bohang cukup baik, tidak semua gambar ilustrasi menampilkan isi teks sebagaimana adanya, namun tetap memenuhi fungsinya dalam mendampingi karya sastra dengan cara memperkuat suasana sesuai dalam teks puisi dan menampilkan makna yang terkandung dalam masing - masing teks puisi.

\section{DAFTAR PUSTAKA}

Aschner, M. J. (1956). Teaching the anatomy of criticism. The School Review, 64(7), 317-322.

Bohang, L. (2016). The Book of Forbidden Feelings. Jakarta: PT. Gramedia Pustaka Utama.

Damono, S. D. (2018). Alih wahana. Gramedia Pustaka Utama.

Dewey, J. (2005). Art as experience. Penguin.

Elo, S., \& Kyngäs, H. (2008). The qualitative content analysis process. Journal of Advanced Nursing, 62(1), 107-115.

Feldman, E. B., \& Woods, D. (1981). Art criticism and reading. Journal of Aesthetic Education, 15(4), 75-95.

Jerome, S. (1966). Aesthetics. Macmillan Press Limited.

Ross, R. (1963). Illustration today. International Textbook Company.

Salam, S. (2017). SENI ILUSTRASI: ESENSISANG ILUSLATOR-LINTASANPENILAIAN. Badan Penerbit unm.

Sudarmaji, D.-D. K. S. R. (1979). Dinas Museum dan Sejarah. Jakarta.

Waluyo, H. J. (2002). Apresiasi puisi: panduan untuk pelajar dan mahasiswa. Gramedia Pustaka Utama. 